\title{
Letting Patients Die: Legal and Moral Reflections
}

\author{
Sanford H. Kadish $\uparrow$
}

Fifty years of medical advances have profoundly challenged some of our most deeply held moral beliefs about life and death. Doctors and hospitals that once would have prolonged life now routinely discontinue lifesustaining treatment. Professor Kadish examines the legal and moral aspects of these decisions. Courts have justified discontinuing treatment on grounds of the patient's right to autonomy. While they have sought to confine their decisions to letting-die situations, the strategy creates an instability, since in principle the right of autonomy extends to choices of suicide, assisted suicide, and active euthanasia. Professor Kadish then considers advance directives and the doctrine courts use when there has been no advance directive, the doctrine of substituted judgment. He argues that advance directives lack the full moral force of contemporary choices and should yield to the current compassionate interests of the patient, as well as to the patient's choice to live even if less than fully competent. Finally, he concludes that courts have gone astray by invoking the principle of autonomy in substituted judgment situations, because autonomy cannot be at issue when the patient has made no choice. Instead, Professor Kadish favors a decision based on the best interests of the patient, taken to mean a decision in conformity with the values and commitments that guided the patient's competent life, and one regardful of the quality of the experiences of the present patient. He rejects a standard that would seek a decision designed to make the patient's life as a whole a better one in any objective sense.

Since World War II dramatic advances in the power of medicine to sustain life have led to profound changes in the types of illness from which people die. At one time pneumoma, influenza, and other communicable diseases were the most common causes of death. ${ }^{1}$ Today chronic,

$\dagger$ Copyright Sanford H. Kadish, 1992, Morrison Professor of Law, Emeritus, Boalt Hall School of Law, University of California, Berkeley. B.S.S. 1942, City College of New York; LL.B. 1948, Columbia University School of Law; Juris Dr. (h.c.) 1983, University of Cologne. This essay was written as a contribution to a Festschrift for Professor Joel Feinberg: IN HARM's WAY: Essays IN HONOR OF JOEL FEINBERG (Jules Coleman et al. eds., forthcoming 1993).

I am indebted to Meir Dan-Cohen, Michael Flick, Mort Kadish, Yale Kamisar, Eric Rakowski, aud Jeremy Waldron for their critical reading and helpful suggestions, and to Daniel Saunders for his faultless research assistance.

1. President's Comm'n for the Study of Ethical Problems in Medicine and 
degenerative diseases such as cancer, heart disease, and cerebrovascular disease have become predominant, accounting for approximately seventy percent of all deaths in the Umited States. ${ }^{2}$ This in turn has shifted the locus of dying. Whereas at the turn of the century most patients died at home, today nearly eighty percent of deaths occur in hospitals. Patients with degenerative diseases can be kept biologically alive for long periods of time through the use of drugs and machines, though sensate and functional life has gone forever. ${ }^{3}$ As a consequence, in the language of one court, "[q]uestions of fate have . . . become matters of choice raising profound 'noral, social, technological, philosophical, and legal questions ...." For example, does keeping people biologically alive in these circumstances inake sense? Whose interests are served by sustaining a life so limited in scope? In what does the value of a life lie? What is the role of the patient's preferences in cases where he has inade a coinpetent current choice, where he has made an eartier choice, where he has made no choice? These questions, thrust upon us by advances in medical technology, raise doubts about the continued validity of some of our inost deeply held moral beliefs about life and death.

Despite soine paradoxes and inconsistencies (for example, in our attitudes toward war, capital pumishment, and risk), preservation of huinan life is generally seen as a supreme good in our culture. ${ }^{5}$ Intentionally taking a life, at least an innocent life, is among the worst wrongs a person can commit. It is everywhere a crime, punishable by the severest penalties known to the law. Every innocent person, no matter what the quality of his life, has a legal right that his life not be taken. ${ }^{6}$ Moreover, so great a value is put on life that a person nray not waive his right to life; killing does not become non-culpable because the victim consented. ${ }^{7}$ For similar reasons, suicide and attempted suicide were crimes at conimon law, ${ }^{8}$ and helping another kill himself is still a crime in inany American states. 9 Finally, although the law does not generally criminalize failure to save another, a physician who intentionally fails to save a

Biomedical and Behavioral Research, Deciding to Forego life-Sustaining Treatment 16 (1983) [hereinafter President's CoMm'N].

2. Robert F. Weir, Abating Treatment with Critically Ill Patients 10-12 (1989).

3. PRESIDENT'S COMM'N, supra note 1, at 17-18.

4. In re Farrell, 529 A.2d 404, 406 (N.J. 1987) (quoting In re Conroy, 486 A.2d 1209, 1220 (N.J. 1985)).

5. See Sanford H. Kadish, Blame and Punishment 109-32 (1987).

6. This is subject to the possible exception of a necessity defense, where the taking of one life is the only way to avoid the death of several. There is moral authority for this defense, but its legal authority in cases of killing is doubtful. Id. at 123.

7. See Glanville Williams, Textbook of Criminal Law 579 (2d ed. 1983).

8. 4 William Blackstone, Commentaries *189; see also Paul Marcus, Suicide: Legal Aspects, in 4 ENCYCLOPEDIA of CRIME AND Justice 1526-27 (Sanford H. Kadish ed., 1983).

9. See George P. Smith, II, All's Well that Ends Well: Toward a Policy of Assisted Rational Suicide or Merely Enlightened Self-Determination?, 22 U.C. DAVIS L. REV. 275, 290-91 \& n.106 (1989). 
patient's life when able to do so may be guilty of some form of culpable homicide. These norms constitute the moral tradition threatened by the remarkable power of medicme to prolong life. How can this moral tradition ever accommodate a dehiberate decision not to use all available medical power to save a life?

Departures from the official pieties usually occur first in our practices and only later in our professions. ${ }^{10}$ So it has been with the issue of life-sustaining treatment. Doctors and hospitals have long engaged in or tolerated practices that contravene the moral tradition I have just described. ${ }^{11}$ For decades doctors and hospitals have accepted what is called negative euthanasia. "Every day ... respirators are turned off, life-perpetuating intravenous infusions stopped, proposed surgery canceled, and drugs countermanded. So-called Code 90 stickers are put on many record-jackets, indicating 'Give no intensive care or resuscita-

10. Other examples of this lag time can be found in the development of no-fault divorce, which came well after the widespread nullification of strict divorce requirements, see MAX RHElNSTEIN, Marriage STABILITY, DivorCE, AND THE LAW 51-105 (1972); Lawrence M. Friedman, Rights of Passage: Divorce Law in Historical Perspective, 63 OR. L. Rev. 649, 664-69 (1984); the legitimation of plea bargaining which followed decades of its widespread but officially denied practice, see Brady v. United States, 397 U.S. 742 (1970); MORTIMER R. KADISH \& SANFORD H. KADISH, DISCRETION TO DISOBEY 83-85 (1973); and the toleration of abortion under certain circumstances before Roe v. Wade, 410 U.S. 113 (1973), see Herbert L. Packer \& Ralph J. Gampell, Therapeutic Abortion: A Problem in Law and Medicine, 11 STAN. L. REv. 417 (1959). There are situations, of course, in which pronouncements of moral principles precede and influence the practices themselves. One thinks of the Supreme Court's extension of the Bill of Rights and of its civil rights decisions, particularly in the Warren era. But these are cases where the change is from the low ground of practice to the high ground of principle, not where the change is the other way around.

11. Despite statutes in over half the states making it crimmal to help another commit suicide, several recent, widely pubhicized imcidents of this kind have occurred. In one case a Rochester doctor described in the pages of the New England Journal of Medicine how he prescribed the barbiturates that a long-standing patient needed to kill herself following her refusal of treatment for a severe forn of leukemia. Timothy E. Quill, Death and Dignity: $A$ Case of Individualized Decision Making, 324 NEw ENG. J. MED. 691, 693 (1991); see Lawrence K. Altman, Doctor Says He Gave Patient Drug to Help Her Commit Suicide, N.Y. Times, Mar. 7, 1991, at A1. An upstate New York prosecutor sought an indictment against the doctor for feloniously assisting another to commit suicide. Criticisun of the prosecution was widespread. The officers and members of the Council of the Society of General Internal Medicine wrote the District Attorney that Dr. Quill's actions "were consistent with the range of acceptable practice of coinpassionate physicians . . ." Letter from Robert H. Fletcher, President, Society of General Internal Medicine, to Charles Siragusa, District Attorney, SGIM NEwS (Society of General Internal Medicine), Oct. 1991, at 5. Significantly, the grand jury declined to imdict. Lawrence K. Altman, Jury Declines to Indict a Doctor Who Said He Aided in a Suicide, N.Y. Times, July 27, 1991, at A1.

Another recently publicized example is the case of Dr. Kevorkian. He connected an Alzheimer's victim to a suicide device he had made, and watched as she pushed a button to operate it and died. The victim had apparently traveled to Michigan in order to use the machine because Michigan law on assisting suicide was ambiguous, there being no statute explicitly making it criminal to help another commit suicide. Lisa Belkin, Doctor Tells of First Death Using His Suicide Device, N.Y. TIMES, June 6, 1990, at A1, B6.

Dr. Kevorkian has since used his machine on other patients who have enlisted his services, and the final chapter on his activities has yet to be written. The "Dr. Strangelove" character of his death-promotional activities, however, has drawn considerable negative reaction. See Rob Carson, Washington's I-119, Hastings Center REP., Mar.-Apr. 1992, at 7, 9. 
tion." "12 And though medical killing on request (active euthanasia) is apparently not common, neither is it unknown in American hospitals. ${ }^{13}$

The public has come largely to accept these practices, principally through the impact of such dramatic and highly publicized cases as In re Quinlan. ${ }^{14}$ In 1976, the New Jersey Supreme Court held that a parent of Karen Quinlan, a young woman in a permanent vegetative state, could authorize removal of a respirator that was keeping Karen biologically ative. ${ }^{15}$ Since then, public opinion polls have revealed an impressive shift of opinion in just one generation from a majority opposed to "pulling the plug" on permanently comatose patients to a large inajority-sometimes nearing $90 \%$-in favor of such measures. ${ }^{16}$ Opimion as to whether doctors should be permitted to actively kill mcurable and coinatose patients has also changed. In 1947 , a majority disapproved. ${ }^{17}$ Since then, majorities of up to $64 \%$ have favored such proposals. ${ }^{18}$

There appears to be even less dissent when the patient is not comatose and competently chooses to die. A recent national survey showed that $79 \%$ of adults support laws allowing terminally ill patients to refuse life-sustaining treatment or to order that it be stopped. ${ }^{19}$ A recent Califorma poll indicates that about $70 \%$ of Califormans feel that the assisted suicide of seriously ill patients who wish to die should be legalized. ${ }^{20}$ In Washington state, voters defeated a referendum proposing that doctors be permitted to kill terminally ill patients at their request by a

12. Joseph Fletcher, Humanhood: EsSays IN BIOMEdical Ethics 149 (1979).

13. See It's Over, Debbie, 259 JAMA 272 (1988) (anonymous letter describing doctor-author's administration of lethal dosage of morphine to patient in great distress and dying of incurable ovarian cancer who asked that death be advanced). Over 150 letters commenting on this letter were received by the editor of the journal. We are told that of those from physicians, $80 \%$ were unfavorable, implying that many, perhaps up to $20 \%$, were supportive. Gcorge D. Lundberg, "It's Over, Debbie" and the Euthanasia Debate, 259 JAMA 2142 (1988) (editorial describing response to letter).

14. 355 A.2d 647 (N.J.), cert. denied, 429 U.S. 922 (1976).

15. Id. at 671-72.

16. Marcia Coyle, How Americans View High Court, NAT'L L.J., Feb. 26, 1990, at 1, 36 (citing National Law Journal/Lexis poll finding $88 \%$ in favor of letting family decide whether to end life support); Andrew H. Malcolm, A Judicial Sanction for Death by Assent, N.Y. Times, June 28, 1987, $\S 4$, at 26 (discussing a shift in public opinion polls to a two-thirds majority in favor of giving patients right to terminate treatment); Clay Richards \& B.D. Colen, Poll: Most Favor "Right to Die" Laws, NEwSDAY, June 10, 1990, at 15 (citing Tines Mirror Center poll finding 80\% supporting right to terminate treatment). The rise of a book on how to commit suicide (Derek Humphry's Final Exit) to the top of the best-seller list further reveals the shift in public attitudes towards death and dying. See Katrine Ames, Last Rights, Newsweek, Aug. 26, 1991, at 40.

17. See Derek HumphrY \& ANN WiCKETt, The Right to Die $35-36$ (1986).

18. Melinda Beck, The Doctor's Suicide Van, Newsweek, June 18, 1990, at 46, 47 (eiting recent Hemlock Society poll reporting $64 \%$ approval); Andrew H. Malcolm, Giving Death a Hand: Rending Issue, N.Y. Times, June 9, 1990, §1, at 6 (citing N.Y. Times/CBS News Poll finding 53\% approval).

19. Richards \& Colen, supra note 16 , at 15.

20. Lisa Belkin, Doctors Debate Helping the Terminally Ill Die, N.Y. TIMES, May 24, 1989, at A1, A25. 
vote of $56 \%$ to $44 \% .{ }^{21}$ But a month earlier a poll showed that, of those likely to vote, $61 \%$ were in favor, $27 \%$ were opposed, and $12 \%$ were undecided. ${ }^{22}$ The defeat of the referendum might have been a manifestation of the "cold feet" phenomenon that sometimes occurs when the voter enters the voting booth. ${ }^{23}$ Despite this apparent setback, the inarked increase in public acceptance of killing terminally ill patients, both in Washington and nationally, has been striking.

Equally striking are the changes in enacted laws. When Karen Quinlan became comatose in 1975, no state recognized a patient's right to set limits on life-prolonging medical efforts. Now, over forty states have passed "living will" statutes ${ }^{24}$ giving effect to a person's clioice of medical treatment im the event of imcompetency. ${ }^{25}$ Altliough these laws tend to be highly restrictive ${ }^{26}$ they nonetheless represent a radical departure from what could have been expected of a legislature a decade earher. More significantly, many states have enacted statutes allowing a person to authorize an agent, $m$ the event of the patient's incompetence, to make those healtli care decisions that the patient could have made if competent. ${ }^{27}$

21. Jane Gross, Voters Turn Down Mercy Killing Idea, N.Y. TIMEs, Nov. 7, 1991, at B16.

22. Peter Steinfels, Beliefs, N.Y. Times, Nov. 9, 1991, at 11; cf. Euthanasia Favored in Poll, N.Y. TIMES, Nov. 4, 1991, at A16 (noting results of October 1991 national poll showing that "nearly two out of three Americans favor doctor-assisted suicide and euthanasia for terminally ill patients who request it").

23. The negative reaction to the exploits of Dr. Kevorkian and his suicide machine, to which wide publicity was given in the days before the vote, is thought by some to have been a contributing factor. For a review of the public debate preceding the vote, see Carson, supra note 11.

24. Introduction to Refusal of Treatment Legislation: A STATE by State Compilation of ENacted and Model Statutes (Society for the Right to Die ed., 1991) [hereinafter REFUSAL OF TREATMENT LEGISLATION]. Living-will statutes had been introduced in state legislatures as early as 1906, but none was enacted until after the Quinlan deeision. Part of the explanation is that the early proposals would lave authorized active euthanasia, while the current crop of statutes excludes it. See 3 JoEl FeINBERG, ThE MORAL LIMITS OF THE Criminal LAW: HARM to SELF 367-68 (1986). California passed the first living-will statute in 1976. See Natural Death Act, Cal. Health \& SAFETY CodE $\S \S 7185-7195$ (West Supp. 1992).

25. Refusal of TREATMENT Legisl.ation, supra note 24.

26. Typically, living-will statutes apply only to persons in permanent vegetative states, or where death is inevitable and inminent and the hiving will is executed after the person becomes terminally ill. They also typically exclude the withdrawal of artificial nutrition and hydration, as well as "affirmative euthanasia." See, e.g., CAL. CIV. CODE $\$ \$ 2430-2444$ (West Supp. 1992) (California's provision for durable power of attorney for health care). For a comprehensive review of state legislation, see generally REFUSAL OF TREATMENT LEGISLATION, supra note 24.

27. There have been a number of studies of judicial developments under these statutes. See, e.g., MaRK A. Hall \& Ira M. EllmaN, Health Care LaW aNd Ethics in a Nutshell 283-88 (1990); Developments in the Law-Medical Technology and the Law, 103 HARV. L. REv. 1519, 1670-72 (1990) [hereinafter Developments]; Rebecca Dresser, Life, Death, and Incompetent Patients: Conceptual Infirmities and Hidden Values in the Law, 28 ARIZ. L. REV. 373 (1986); Linda C. Fentinan, Privacy and Personhood Revisited: A New Framework for Substitute Decisionmaking for the Incompetent, Incurably Ill Adult, 57 GEo. WASH. L. REV. 801, 818-40 (1989); Nancy K. Rhoden, Litigating Life and Death, 102 HARv. L. REv. 375, 375-437 (1989). The strength of public policy behind these laws is evident in the federal Patient Self-Determination Act, amending the Social Security Act, which seeks to assure wider publicity to state laws permitting patients to refuse 
In light of this sea cliange in public, inedical, and legislative judgments, it was inevitable that American courts would be called upon to respond. Since the 1975 watershed opinion in the Quinlan case, there have been inany cases from the state and federal courts, with most decisions autliorizing letting the patient die. These cases will figure prominently in this paper. Part I describes the courts' development of the right of autonomy, their use of it as the basis for changing the law, and the ways they sought to limit the scope of change portended by full application of that concept. Parts II and III deal with the problem of determining when patients inay be left to die when the right of autonomy is not fully applicable, as in cases of advance directives, or not applicable at all, as in cases where the patient never made a choice during his competent life.

\section{I}

\section{Autonomy and the Competent Patient}

The fulcrum on which the courts moved the law away from its traditional hostility to forgoing treatınent was the concept of consent. The requirement of consent goes back to the coininon law, which made it a battery to subject a person to any force to which he liad not consented, including such force as might be involved in providing medical treatment. ${ }^{28}$ In dealing with such issues as the constitutionality of laws prohibiting contraception and abortion, the United States Supreme Court gave new and powerful support to the coinmon law concept of consent. ${ }^{29}$ The Court developed a jurisprudence of autonomy (sometimes under the misleading label of privacy), finding in the Constitution a fundamental right of mdividuals to make choices with regard to their own bodies. The lesson of the new autonomy jurisprudence for refusals of medical treatment was plain, and the Quinlan case ${ }^{30}$ was one of the first to draw it explicitly. In that case the New Jersey court found that just as the constitutional right of autonomy over one's body encompasses a woman's decision to have an abortion, so does it "encompass a patient's decision to decline medical treatment," at least under some circuinstances. ${ }^{31}$

treatment. Omnibus Budget Reconciliation Act of 1990, Pub. L. No. 101-508, $\S 4751$, 104 Stat. 1388, 1388-204 to -206. Among other things, it requires medical institutions receiving Medicare or Medicaid funds to provide all patients witls written information on their rights under state law to refuse medical care, including information on advance directives. It also requires the Secretary of Health and Human Services to develop and distribute informational materials on these subjects.

28. See Schloendorff v. Society of N.Y. Hosp., 105 N.E. 92, 93 (N.Y. 1914) (Cardozo, J.) ("Every human being of adult years and sound mind has a right to determine wliat shall be done with his own body; and a surgeon who performs an operation without his patient's consent cominits an assault ... ."), overruled on other grounds by Bing v. Thunig, 143 N.E.2d 3 (N.Y. 1957).

29. See Roe v. Wade, 410 U.S. 113 (1973) (right to abortion); Eisenstadt v. Baird, 40 U U.S. 438 (1972) (same); Griswold v. Connecticut, 381 U.S. 479 (1965) (right to aceess to contraception).

30. In re Quinlan, 355 A.2d 647 (N.J.), cert. denied, 429 U.S. 922 (1976).

31. Id. at 663 . 
Other courts soon followed the Quinlan lead. ${ }^{32}$

In Cruzan v. Director, Missouri Department of Health, ${ }^{33}$ the United States Supreme Court, in an opinion by Chief Justice Rehnquist, went a good distance toward lending its authority to a constitutional right to refuse medical treatinent. The case involved a Missouri statute requiring that before artificial nutrition and hydration could be withdrawn from a patient in a permanent vegetative state, it must be established by "clear and convincing" evidence that she had decided when coinpetent not to be kept alive in these circumstances. ${ }^{34}$ Although upholding the constitutionality of the Missouri standard, the opinion stated that the logic of the Court's prior opinions supported the existence of a patient's constitutionally protected interest in rcfusing lifc-sustaining medical treatinent, including artificial nutrition and hydration. ${ }^{35}$

As the Court further noted in Cruzan, however, the existence of a constitutionally protected interest does not necessarily preclude state regulation, for a state might have sufficiently weighty imterests to override that of the individual. ${ }^{36}$ Indeed, state and lower federal courts have recognized four distinct state interests that weigh against the choice of a competent patient to decline treatment: 1) its interest in preserving life as such; 2) its mterest in preventing suicide; 3) its interest in protecting the interests of innocent third parties; and 4) its interest in inaintaining the ethical integrity of the medical profession. ${ }^{37}$ Only the first two figure at all seriously in the decisions, however. ${ }^{38}$ Though soine courts have treated the interest in preserving life and the interest in preventing suicide separately, ${ }^{39}$ they are obviously interrelated considerations. ${ }^{40}$ It is noteworthy, however, that lower courts in virtually all cases have upheld

32. See Developments, supra note 27, at 1661-65. Since Quinlan, courts have upheld with substantial unanimity the right of competent patients (under state or federal law) to reject lifesustaining treatment, at least in cases of terminal disease. Id. at 1645. Some have affirmed this right where competent patients were suffering painful and incurable ailments; many have extended the right to include rejection of artificial nutrition and hydration. A review of the case law may be found in the materials cited supra note 27.

33. 110 S. Ct. 2841 (1990).

34. Id. at 2854 .

35. Id. at 2852 .

36. Id.

37. See Superintendent of Belchertown State Sch. v. Saikewicz, 370 N.E.2d 417, 425 (Mass. 1977); In re Conroy, 486 A.2d 1209, 1223 (N.J. 1985).

38. See Martha A. Matthews, Comment, Suicidal Competence and the Patient's Right to Refuse Lifesaving Treatment, 75 CALIF. L. REv. 707, 729-43 (1987). In the early Jehovah's Witness blood transfusion cases, however, some courts gave as a further reason for compelling life-saving transfusions the interests of the patient's minor children. Id. at 732-33.

39. See, e.g., Bartling v. Superior Court, 209 Cal. Rptr. 220, 225 (Ct. App. 1984); Brophy v. New England Sinai Hosp., 497 N.E.2d 626, 635-38 (Mass. 1986).

40. See Conroy, 486 A.2d at 1224 ("This state interest in protecting people from direct and purposeful self-destruction is motivated by, if not encompassed within, the state's more basic interest in preserving life. Thus, it is questionable whether it is a distinct state interest worthy of independent consideration."). 
the right of a patient to reject life-sustaining treatment as required by a constitutional right of autonoiny, and as such outweighing these state interests. ${ }^{41}$

The problein that naturally arises concerning this right of autonomy is its extent. Does it coine into play only in these inedical contexts, or does it extend to all cases in which the person chooses to achieve his own death, including perhaps those in which he obtains the help of another to further his choice? Courts have declined to extend the right of autonoiny to nonmedical contexts and have sought to avoid doing so by distinguishing medical letting-die situations from conventional suicide and consensual euthanasia. Since such an extension would profoundly unsettle existing mores and might raise fornidable problems for the law in preventing exploitation and abuse, it is not hard to understand the courts' motivation. Still, putting prudential considerations aside for the moinent, can these distinctions withstand principled analysis?

One ground on which courts have sought to distinguish letting-die situations from conventional suicide is that the latter requires affirmative life-taking actions. On this view a patient refusing to be attached to an apparatus necessary for his survival is not taking his life, but is simply letting nature take its course. Hence death is caused by the disease, not by the person himself, ${ }^{42}$ nor by the physician who respects his wishes. How persuasive is this distmction? Perhaps there is soine support for this approach im the legal principle that imposes no duty to act to prevent a prohibited harm except in specified circumstances. After all, the traditional formulation of the ban on suicide is cast in ternis of action, ${ }^{43}$ so it is arguable that one who seeks death through inaction would not fall within the ban. ${ }^{44}$ Yet it would be odd if that were so. The traditional dismclination of Anglo-American courts to interpret prohibitions on

41. See supra note 32.

42. See, e.g., Satz v. Perlmutter, 362 So. $2 d$ 160, $162-63$ (Fla. Dist. Ct. App. 1978), aff'd on opinion below, 379 So. $2 d 359$ (Fla. 1980); Superintendent of Belchertown State Sch. v. Saikewicz, 370 N.E.2d 417, 426 n.11 (Mass. 1977) ("[T]o the extent that the cause of death was from natural causes the patient did not set the death producing agent in inotion ...."); Conroy, 486 A.2d at 1224 ("Refusing medical intervention inerely allows the disease to take its natural course; if death were eventually to occur, it would be the result, primarily, of the underlying disease, and not the result of a self-inflicted injury."); see also Nonnan L. Cantor, The Permanently Unconscious Patient, NonFeeding and Euthanasia, 15 AM. J.L. \& MED. 381, 433 (1989) ("The assertion that rejection of lifesaving medical treatment by competent patients constitutes suicide has been uniformly rejectedusually based on a distinction between letting nature take its course and initiating external deathcausing agents.").

43. See, e.g., 4 Blackstone, supra note 8 , at *189 ("A felo de se therefore is he that deliberately puts an end to his own existence....").

44. Deliberately starving oneself to death tends to strike people as suicide, although legal authority for that view seems limited to cases approving the force-feeding of prisoners, a very special situation involving the state's interest in the administration of the criminal justice system. The cases cited by Justice Scalia in his concurring opinion in the Cruzan case are of this kind. See Cruzan v. Director, Mo. Dep't of Health, 110 S. Ct. 2841, 2861 (Scalia, J., concurring). 
causing certain results as requiring action to prevent those results is based on the value of the freedoin of the individual not to be constrained by the interests of others. That value is not at stake in the prohibition of suicide for two reasons: first, because the interests of others are not necessarily involved, and second, because the ban on suicidal actions already constitutes a inajor inroad upon the person's freedorn, so that excluding cases of passive choice to die out of concern for that very freedoin would be eccentric at best.

In any event, if we view the issue in terms of moral principle rather than legal doctrine and take the traditional anti-suicide position as a serious starting point, the distinction between intentionally killing oneself and intentionally submitting to an avoidable death is suspect. There is disagreement over the general moral significance of the distinction between doing and letting happen, ${ }^{45}$ but the intuitive appeal of the distinction is less in some cases than in others, and its appeal seems particularly weak im cases of treatment refusal. ${ }^{46}$

Consider a patient who finds himself attached against his will to some life-sustaining apparatus he had earher exphicitly rejected. He removes it for the saine reason he earlier rejected it-he prefers death to living attached to a machine-and dies inoments later. Presumably this would constitute suicide, since he achieved his death by positive actions. But could we justifiably say that if the doctors had followed his instructions and lie liad died, this would not be suicide because his death would then not have been caused by the patient's actions? Or consider an analogous case: a paralyzed man, sitting on a beach threatened by an incoming tide, deliberately, in order to end his life, declines to allow a lifeguard to move him out of harm's way, and drowns in consequence. (To make the analogy closer, assume lie took no action to place himself in danger from the tide-say, for exainple, he was initially placed there against his will.) Would it not be correct to see this as a suicide? Yet the person dying of a disease who chooses not to permit soine medical intervention that would save him is in no different a situation.

We might have good reasons to think that in certain circuinstances intentionally achieving one's death is justifiable, or that it is less blameworthy in some circumstances than in others. Moreover, we may for these reasons, or indeed for other reasons of a inore practical and prudential character, want to call it something else. But as a matter of prin-

45. See generally Jonathan Glover, Causing Death AND Saving Lives 92-112 (1977); Warren S. Quinn, Actions, Intentions, and Consequences: The Doctrine of Doing and Allowing, 98 PHIL. REV. 287 (1989).

46. Accord Conroy, 486 A.2d at 1233-34 (rejecting "the distinction that some have unade between actively hastening death by terminating treatment and passively allowing a person to die of a disease as one of limited use in a legal analysis of such a decision-making situation"); PRESIDENT's COMM'N, supra note 1, at 4,65-72 (discussing problem of overreliance on act/omission distinction and difficulty of evaluating moral significance of acts and omissions causing death). 
ciple, that a person achieves his goal by refusing necessary medical intervention hardly seeins a better reason to treat his action differently than that a person achieves his goal by letting the tide come to him rather than gomg to it. ${ }^{47}$

Another approach some courts have taken is to define suicide to require a purpose to take one's own life, sometimes called a specific imtent. Those who reject treatment, it is reasoned, do not want to die; indeed, as one court put it, "they may fervently wish to hive, but to do so free of unwanted medical technology, surgery, or drugs, and without protracted suffering." 48 When they reject treatment, therefore, they are not committing suicide. ${ }^{49}$ Recently Ronald Dworkin has lent his considerable authority to this position. ${ }^{50}$ In the course of criticizing Justice Scalia's argument in Cruzan that the venerability of the tradition of state condemnation of suicide establishes the state's equal entitlement to regulate treatınent refusal,${ }^{51}$ Dworkin asserts that it is "bizarre to classify as suicide someone's decision to reject treatment that would keep him alive but at a cost he and many other people think too great." 52 He appears to be inaking two points: the first, that death is achieved by failing to act, I have already discussed; the second, that the person's dccision is not suicide because his intention is not to achieve his death as such, but to avoid a life whose burdens are not worth the hiving, is an arguinent I take to be equivalent to the specific intent argument.

A case may be made for the specific intent argument in this context along the following hines. The purpose of the classic suicide in inflicting a mortal mjury on himself, in the sense of purpose as the "conscious

47.

It would not make much sense to say that one may not kill oneself by walking into the sea, but may sit on the beach until submerged by the incoming tide; or that one may not intentionally lock oneself into a cold storage locker, but may refrain from coming indoors when the temperature drops below freezing.

Cruzan, 110 S. Ct. at 2861 (Scalia, J., concurring).

48. Conroy, 486 A.2d at 1224; see also Superintendent of Belchertown State Sch. v. Saikewicz, 370 N.E.2d 417, 426 n.11 (Mass. 1977) ("[I]n refusing treatment the patient may not have the specific intent to die.").

49. See, e.g., Conroy, 486 A.2d at 1226 ("'[R]ejecting her artificial means of feeding would not constitute attempted suicide, as the decision would probably be based on a wish to be free of medical intervention rather than a specific intent to die, and her death would result, if at all, from her underlying medical condition ...."). For a discussion of the cases and a criticism of the distinction, see Matthews, supra note 38 , at $735-38$.

50. See Ronald Dworkin, The Right to Death, N.Y. Rev. Books, Jan. 31, 1991, at 14.

51. Cruzan, 110 S. Ct. at 2859 (Scalia, J., concurring).

52. Dworkin, supra note 50 , at 17 . He goes on to say:

Many people whose lives could be lengthened through severe amputations or incapacitating operations decide to die instead, and they are not thought to have taken their own lives for that rcason... . People imagining themselves as permanently comatose are in the same position: their biological lives could then be prolonged only through medical treatment they would think degrading, and only in a form they would think worse than death. So it is a mistake, for that rcason, to describe someone who signs a living will Id. as committing hypothetical suicide. 
object" of an action, ${ }^{53}$ is to cause his own death. The same cannot be said of all cases where the person refuses treatment he knows is necessary to keep him alive. In some of these cases his mental state with respect to his death is more properly characterized as knowledge rather than purpose; $^{54}$ that is, although he knows that his conduct will result in his death, his conscious object is not to die, but to be free of the medical treatment. That his object is not to die may be seen by noticing that if, contrary to the prediction of his doctors, he recovered without the treatment, his purpose would not be frustrated. The same could not be said of the classic attempted suicide.

The trouble with this line of argument is that the distinction between purpose and knowledge in this context is without inoral relevance. The cases where the refusal of treatinent can be said not to refiect a specific intent to die are those in which the irremediable condition which makes hiving not worthwhile to the person is prospective rather than already existing. If it is in prospect, we are able to see his purpose as avoiding his affliction. But when the afflictive condition already exists, the ending of the person's afflicted life would presumably be seen as his purpose in refusing treatınent. So, for example, if a patient refuses amputation of his gangrenous legs (because he doesn't want to live without thein), his purpose is to avoid the amputation, not to die, so that his subsequent death would not be considered a suicide. He would have been pleased to live if his legs could have been saved. But if a person whose legs have already been amputated refuses medical treatment necessary for his recovery (again because he doesn't want to hive without his legs), his purpose is to die, so that his subsequent death would be deened a suicide. But except in the case where deatli is itself souglit as an end (the insured who wants his beneficiary to recover on his hife insurance, for example), all suicides are motivated by the desire to end experiencing something unbearable in that person's life. It is hard to see any point in treating choices to end one's life differently depending on whether the motivating condition is present or anticipated.

I suggest, therefore, that the efforts by courts to maintain the traditional authority of the state over suicide by distinguishing it from refusal of treatment do not withstand scrutiny. I do not inean to suggest that the law cannot justifiably inake distinctions on pragmatic grounds; it frequently does so for all kinds of prudential considerations. I inean only to suggest tliat the distinctions under discussion cannot be defended except on pragmatic grounds.

Consider the basic argument courts and commentators make on

53. See Model Penal Code $§ 2.02(2)$ (a) (1985) (a person acts purposely with respect to a result of his conduct if "it is his conscious object to ... cause such a result").

54. See id. $\$ 2.02(2)(b)$ ("A person acts knowingly with respect to . . . a result of his conduct [if] he is aware that it is practically certain that his conduct will cause such a result."). 
behalf of the right to refuse treatment. The argument is that the choice between medical treatment and death is so fundamental that it is protected agamst state control by a constitutional right of autonomy. That being the case, however, there is no principled basis for denying the same freedom of choice to those not dependent on medical treatment for survival. The failure of efforts to distimguish suicide from refusal of treatment is attributable not simply to usage and definition, but to the equivalence between the two. The moral case for autonomy extends to both if it extends to one.

It isn't hard to surmise why courts have drawn back from the conclusion that there is no difference between suicide and refusal of treatment. To accept it would be to acknowledge a radical break with the received tradition and open the door to positions the courts are not yet willing to adopt: for example, that the state may not act to prevent suicide (except perhaps temporarily to assure competent consent), ${ }^{55}$ or to prevent a person from assisting another's suicide, or conceivably even to prevent one person from killing another who competently consents to being killed. ${ }^{56}$ By "open the door" I do not mean that courts would be compelled by consistency to adopt these positions. There might well be compelling practical considerations for not doing so, such as fear of

55. See Matthews, supra note 38 , at 754-57 (suggesting that state interest should be held to extend only to preventing irrational suicides and proposing a test for determining competence).

56. Cf. FeINBERG, supra note 24, at 374 (arguing that only possible justification for state to continue prohibiting euthanasia is a "pragmatic" fear of mistake or abuse); Alister Browne, Assisted Suicide and Active Voluntary Euthanasia, 2 CAN. J.L. \& JURIS. 35 (1989). But cf. Phillipa Foot, Commentary: Active Euthanasia with Parental Consent, HASTINGs CENTER REP., Oct. 1979, at 20 (maintaining that it is easier to justify "passive" euthanasia than it is to justify "active" euthanasia). Occasionally one finds a judge making the argument. See, e.g., Bouvia v. Superior Court, $225 \mathrm{Cal}$. Rptr. 297, 308 (Ct. App. 1986) (Compton, J., concurring). In Bouvia, the court authorized the removal of a nasogastric tube from a competent but permanently paralyzed young woman who preferred to starve herself to death rather than to continue living. The concurring judge criticized the majority for uot admitting that

[t] the right to die is an integral part of our right to control our own destinies so long as the rights of others are not affected. That right should, in my opinion, include the ability to enlist assistance from others, including the medical profession, in making death as painless and quick as possible.

Id. at 307.

It is interesting to note that almost 20 years ago, before the Quinlan case launched the current rethinking of the right to die, Professor Glanville Williams advocated that proponents of euthanasia adopt as an interim strategy the distinctions to be found in Catholic doctrine between killing and letting die and between ordinary and extraordinary treatment. Glanville Williams, Euthanasia, 41 Medico-Legal J. 14, 18 (1973). He observed:

If this distinction between an act and an omission is thought to be artificial, its artificiality is imposed on us by our refusal to accord the same moral freedom for action as we do for inaction. Pending a change of thought, the concept of an omission is a useful way of freeing ns from some of the consequences of overrigid moral attitudes.

Id. at 21 .

For a fuller account of the story of the success of Professor Williams' proposal, see Yale Kamisar, When Is There a Constitutional "Right to Die"? When Is There No Constitutional "Right to Live"?, 25 GA. L. REv. 1203, 1214, passim (1991). 
abuse and difficulties of administering controls to prevent such abuse. ${ }^{57} \mathrm{I}$ mean only that, by not distinguishing suicide and consensual euthanasia, the courts would by implication be endorsing these positions in principle. Yet this would be the greatest affront to the moral tradition. The courts, therefore, have chosen to improvise lines of distinction, even at the cost of some coherence. The distinctions permit results that courts regard as right in the medical context while giving at least the appearance of continuity with the established tradition and avoiding positions that may be either impractical or preinature. As I have suggested, it is not unusual for coininon law courts to adopt lines of distinction out of unspoken considerations of strategy rather than of logic and principle. This is such a case.

Another way, besides distinguishing suicide, that courts have sought to confine the precedent of permitting patients to refuse life-sustaining treatment has been to stress the special circumstances of the particular case. Courts have emphasized that the patient was soon to die in any event, ${ }^{58}$ or that he was in a permanently comatose condition, ${ }^{59}$ or that the medical treatment was complicated and imtrusive ("extraordinary"). ${ }^{60}$ The implication is that when the patient is not dying, but instead has some appreciable time to hive, or when he is sensate, or when the treatinent is not unusual and intrusive ("ordmary"), then the interests in preserving life as such and preventing suicide will prevail, and the patient will be coinpelled to subint to treatment.

It is hard to be sure whether the courts really mean this, or whether the qualifying language is meant as sugar-coating to make the inedicine go down. If the former, then much of the talk of autonomy in the cases is window dressing. After all, if what makes it proper to forgo treatment is the patient's inviolable right to choose, his choice cannot be dependent on a court's willinguess to let him have his way in some circumstances but not in others. Therefore, to the extent courts contmue to insist that his choice is so dependent, they can no longer seriously defend permitting him to die on the ground that it is the patient's inviolable choice that

57. See FeInBERg, supra note 24, at 374; LAURENCE H. TRIBE, AMERICAN CONSTITUTIONAL LAw 1370-71 (2d ed. 1988). Recently, Professor Feinberg has challenged this pragmatic justification on the ground that it falsely assumes it is always a greater evil to let a patient die by mistake than to keep hin alive by mistake. Joel Feinberg, Overlooking the Merits of the Individual Case: An Unpromising Approach to the Right to Die, 4 Ratio JURIS 131 (1991).

58. See, e.g., Tune v. Walter Reed Army Hosp., 602 F. Supp. 1452, $1455-56$ (D.D.C. 1985); Satz v. Perlmutter, 362 So. 2d 160, 162 (Fla. Dist. Ct. App. 1978), aff'd on opinion below, 379 So. 2d 359 (Fla. 1980).

59. See, e.g., In re Guardianship of Barry, 445 So. $2 \mathrm{~d} 365,371$ (Fla. Dist. Ct. App. 1984); In re Peter, 529 A.2d 419, 424 (N.J. 1987); In re Quinlan, 355 A.2d 647, $663-64$ (N.J.), cert. denied, 429 U.S. 922 (1976).

60. See, e.g., Superintendent of Belchertown State Sch. v. Saikewicz, 370 N.E.2d 417, 423-24 (Mass. 1977) (extraordinary inethods to prolong hife not required); Quinlan, 355 A.2d at 667-68 (what is ordinary for curable patient inay be extraordinary for terminal patient). 
they are enforcing and not their own. I expect that, in the end, these qualifying limitations are not likely to survive as part of the jurisprudence of forgoing inedical treatinent. ${ }^{61}$

II

\section{Autonomy AND the Incompetent Patient}

The right of autonoiny, then, is what ensures that a patient inay refuse treatment. But autonomous choice requires a coinpetent chooser. What of the inany cases where the patient is not coinpetent? The response of the courts has been to rest on the intriguing arguinent that since incompetency cannot diminish a person's rights, denial of an incompetent's choice would constitute unconstitutional discrimination on grounds of personal handicap. ${ }^{62}$ At the outset, therefore, the cases of incompetents raise a formidable conceptual problein. How can the right of autonomy over one's own body have any apphication where the patient is incoinpetent to inake a choice? Whatever rights an incompetent person inay be said to possess, how can autonomous choice be one of them when incompetency means precisely the inability to exercise choice? ${ }^{63}$

The current state of law in the area can be briefly sumnnarized. ${ }^{64}$ If the incompetent patient, at some time when he was conıpetent, exercised his right to refuse inedical treatment under circumstances like those now presented (possibly, but not necessarily, by a formal "advance directive" in a hiving will), the courts have been willing in inost situations to give effect to that choice. Courts have also given effect to choices by patients who, while competent, authorized another to inake the choice in the event of his incompetence (by a so-called "durable power of attorney"). If, during competency, the patient did not execute an advance directive, appoint an agent, or indicate a choice in soine other way (which is the usual case), ${ }^{65}$ the courts have invoked the concept of "substituted judgment" (sometimes called "surrogate decision-making"). Under this

61. The extraordinary/ordinary distinction seems already defunct. See, e.g., In re Conroy, 486 A.2d 1209, 1234-36 (N.J. 1985) (decided nine years after Quinlan by same court, rejecting any distinction between ordinary and extraordinary treatment or between termination of artificial feedings and termination of other forms of life-sustaining medical treatment); PRESIDENT's CoMm'N, supra note 1, at 82-89 (criticizing distinction as hopelessly ambiguous). Professor Kainisar has concluded, "The extraordinary/ordinary means distinction has been widely criticized and is now widely rejected." Kamisar, supra note 56, at 1220.

62. See, eg., Saikewicz, 370 N.E.2d at 428 (failing to grant "the same panoply of rights and choices" to coinpetent and incompetent persons "downgrade[s] the status of the incompetent person by placing a lesser value on his intrinsic human worth and vitality").

63. For a definitive treatinent of these issues, see generally AllEN E. BUCHANAN \& DAN W. BROCK, DECIDING FOR OTHERS (1989).

64. For a discussion of the cases, see references cited supra note 27.

65. The United States Senate's proposed Patient Self Determination Act of 1989, supra note 27 , recites in its statement of purposes and findings that "[e]stimates identify that 9 percent of the adult competent population have signed a living will; much less than 9 percent have designated a durable power of attorney for health care." S. 1766, 101st Cong., 1st Sess. § 2(b)(5) (1989). 
approach, the decider (the court, the family, or others-courts have disagreed on whether judicial intervention is necessary ${ }^{66}$ inakes the choice on behalf of the incoinpetent.

\section{A. Where the Patient Made a Competent Choice in the Past: Advance Directives}

I will start with situations that seein to ine to present the least difficulty, those where the patient has inade an actual choice in the past. One set of such cases occurs when the patient is in a vegetative state that is known to be permanent. Lacking capacity now and forever for having experiences of any kind or for inaking a different choice, there is no basis for not respecting his earlier competent clioice to die.

Cases at the other extreine, those in which the person remains competent, are also easy. If a competent patient decides to change his mind for some reason-perhaps because of new inedical treatments, or because facing dying as a present reality is different from facing it as a future possibility, or perhaps because he has sinply inellowed with age-the principle of autonoiny requires, not just permits, that he inay do so. Assuming there is no question of the patient's competence (a problem I will return to shortly), ${ }^{67}$ the principle of autonony requires the person's latest choice to govern.

The hard case is presented wlien a patient, plainly incoinpetent on traditional criteria, is still sentient. Consider this hypotlietical. Coinposer Then is a famous inusician whose whole life centers around music. She executes a durable power of attorney in favor of her son, instructimg him that if she becoines permanently unable to experience inusic in any way, needs inedical treatinent to save her life, and is not competent to exercise choice, then no inedical treatinent should be administered to keep her alive. Assume that years later she is in precisely this condition, a victim of senile dementia, as well as of a lifethreatening but readily curable disease. Call her Coinposer Now. Though disabled in the ways I have described and lacking competence as traditionally conceived, she still has some awareness and has the capacity for sensations. For example, suppose Coinposer Now smiles at the sight of her grandchildren, she is apparently comforted by sitting in a garden or by being attended and talked to, and sle shows preferences in foods and television programs. Moreover, she gives no sign of being uncoin-

66. Compare In re Quinlan, 355 A.2d 647, 664 (N.J.) (decision by guardian and family), cert. denied, 429 U.S. 922 (1976) with Saikewicz, 370 N.E.2d at 435 (judicial resolution required) and In re Spring, 405 N.E.2d 115, 120-21 (Mass. 1980) (listing factors to be considered in determining whether prior judicial approval is required).

67. See infra text accompanying notes 83-87; see also Michael R. Flick, The Due Process of Dying, 79 CALIF. L. REv. 1121, 1142-43 (1991) (discussing Bartling v. Superior Court, 209 Cal. Rptr. 220 (Ct. App. 1984), in which the patient vacillated between a desire to die and a desire to live). 
fortable, in pain, or unhappy. Finally, when asked if she prefers to be left to die, she becoines agitated and says no, though how inuch she understands is unclear. (Shortly I will also consider the hypothetical without this last circumstance.)

Should doctors be authorized or required not to treat the curable disease Coinposer Now has contracted because Coinposer Then would not have wanted her life to continue in these circumstances? Does vindication of Composer Then's autonomy require it? Or inust Coinposer Then's earher choice yield to Coinposer Now's present interest in continuing to experience the limited life available to her, as she now seeins to want? ? $^{68}$

Ronald Dworkin would apparently hold that Composer's right of autonomy requires that her eartier competent wish be respected:

A competent person's right to autonomy requires that his past decisions, about how he is to be treated if he becomes demented, be respected even if they do not represent, and even if they contradict, the desires he has when we respect them, provided he did not change his mind while he was still in charge of his own life. ${ }^{69}$

As Dworkin emphasizes elsewhere, he reaches this conclusion even in the harder case where the demented person "imsists on and pleads for" medical treatment. ${ }^{70} \mathrm{He}$ argues that autonomy is the right to govern one's life as a whole and not only part of it, so the right must extend throughout the life of the person-including the period of his incompetency, whether permanent or teinporary (Dworkin calls this the "integrity" view of the person). ${ }^{71}$ To fail to recognize the right of the person when coinpetent to control his fate when incompetent violates what Dworkin calls the right of "precedent autonomy," whose point is to enable us "to lead our own hives rather than being led along them, so that each of us can be ... what he has made himself." 72

68. Various positions in an ongoing philosophical debate over the nature of the self carry implications for how these questions should be answered. Some philosophers hold psychological continuity essential for determiring the boundaries of the self. See DEREK PARFIT, REASONS AND Persons 204-07 (1984); Donald Regan, Paternalism, Freedom, Commitment, in Paternalism 113, 126 (Rolfe Sartorius ed., 1983). On this view, Composer Now, totally lacking psychological continuity with Composer Then, would be a wholly different person for moral purposes and therefore should not be governed by Composer Then's choices. See Dresser, supra note 27, at 381. Others contest this theory of selfhood, instead stressing the moral importance of physical continuity. See Ronald Dworkin, Autonomy and the Demented Self, 64 Milbank Q. 4 (Supp. 2 1986); Rhoden, supra note 27, at 410-19. I will not here pursue the issue in these terms. See generally Allen E. Buchanan, Advance Directives and the Personal Identity Problem, 17 PHIL. \& PUB. AfF. 277 (1988).

69. Dworkin, supra note 68, at 13.

70. Ronald DWorkin, U.S. Congress, OfFice of TEChNology ASSESSMENT, Philosophical Issues Concerning the Rights of Patients Suffering Permanent DEMENTIA 49-50 (1987), microformed on Philosophical, Legal, and Social Aspects of Surrogate Decisionmaking for Elderly Individuals, CIS No. OTA J952-30 (Congressional Info. Serv.).

71. Dworkin, supra note 68 , at $8-9$.

72. Id. at 8. 
I do not dispute that the right of autonomy extends to having one's earlier clioices govern during periods of later incompetence-Ulysses' sailors would have been on solid moral ground in refusing to untie him as they passed the sirens, even if they could liave heard his orders to do so. Nor do I hold that a person's right of autonomy may not be violated if he can never experience its violation, as is true of a person who will never regain his competence. ${ }^{73}$ Rather I will argue two propositions: first, that in our Composer case (im contrast to Ulysses' case) precedent autonomy is not as compelling as an exercise of contemporary autonomy (a current choice) would be; second, that such moral force as precedent autonomy has is morally overridden by considerations of human compassion. ${ }^{74}$

Dworkin tells us that he asked a number of people what they would prefer if they were suffering from senile dementia. He reports that they expressed a preference to be left to die. ${ }^{75} \mathrm{I}$ think he would have gotten a much inore mixed response if he had asked a different question-not what they would prefer for themselves if they were someone like Composer Now, but what they would do if they were responsible for deciding whetlier to treat Composer Now. A nuinber of people to wliom I liave put botll questions answer Dworkin's question the way he reports, but answer my question the opposite way. They theinselves would prefer to be left to die ratlier than to hang on to a life so limited. They are not so ready, however, to inflict the same fate on another person on the basis of their own preference. But why not, if the patient indicated in lier advance directive that that was her preference also? The reason, I suggest, is a well-founded lack of confidence in the force of the earlier directive not to treat.

Solne discounting of the advance directive in the Composer case is warranted on two grounds. First, the fact that advance directives are executed as future hypothetieals deprives them of the full moral force of conteinporary clioices. Unforeseen clianges, sucli as new medical treatments, may substantially alter the person's interests. Moreover, the effect of severe, life-imperilling illness may well produce a marked revision in the attitudes and values of the person. ${ }^{76}$ Indeed, even absent such traumas, it is common for a person to reach very different conclusions depending on whether he is imagining a future hypotletical situation or confronting an immediate, real predicament. What people thought they would want often turns out to be very different from what they do

73. See infra text accompanying notes 114-15.

74. It is unclear whether Dworkin would agree. He recognizes that his conception of precedent autonomy has "austere consequences," but his discussion leaves uncertain whether he means by this that it might be morally correct to override autonomy in such cases, or that it would be understandably difficult for people to resist being humane. Dworkin, supra note 68, at 13 .

75. Dworkin, supra note 70 , at $39,46,101$.

76. Dresser, supra note 27 , at 381. 
want. ${ }^{77}$ Finally, as Buchanan and Brock have pointed out, an advance decision to forgo life-preserving treatinent is less likely than a conteinporaneous choice to elicit protective and supportive responses from persons close to the patient; hence, this informal safeguard against hasty and illconsidered action is not usually present in the case of advance directives. ${ }^{78}$ In view of these considerations, disregard of the advance directive would not constitute as deep an inroad into the autonony principle as would disregard of a contemporaneous clioice.

This conclusion, of course, rests on the premise that at least one inajor element in the rationale for respecting autonomy is that people are normally the best judges of their own interests-for the reasons just given, this rationale is less well-grounded in cases of decisions to die in future circumstances radically different from those experienced by the person at the time of decision. Dworkin rejects this rationale of autonomy, however, (the "evidentiary" view, he calls it) ${ }^{79}$ in favor of the integrity view, which makes the decisive point of autonomy the riglit to govern the course of one's life, including one's incoinpetency, according to a "recognized and coherent scheme of value." of the virtues of autonoiny, but as I argue below, it is unduly limiting to give it the paranoimt place that Dworkin gives it. ${ }^{81}$

The second ground for discounting the advance directive is simply that Composer Now lias subsequently indicated that she prefers to live. Of course, this would be determinative if she were competent. The question is whether to disregard it because she is not. I do not think that we should. Competence is a matter of degree and depends upon the kinds of action at issue. ${ }^{82}$ Impaired people have varying capacities to think, reason, and evaluate, and some actions will call for less of these capacities than will others. A person may lack competence to make a will, for example, but be perfectly competent to clioose whether to watch television or go to the beacli. It seeins to me that an expression of a wisl to live, even by a person incoinpetent for most other purposes, is entitled to

77. See Yale Kamisar, Euthanasia Legislation: Some Non-Religious Objections, 42 MINN. L. REv. 969, 989 (1958). This is one of the major arguments for not holding a surrogate mother to her agreement with the infertile couple who retained her. See MarTHA A. FIELd, Surrogate MOTHERHOOD 69-70 (1988); Stacey Okun, Ruling Hailed by Opponents of Surrogacy, N.Y. TIMES, Feb. 4, 1988, at B7 (snrrogates may change their minds because at time of contract they are unable to project their feelings at time of birth).

78. BuChaNAN \& BROCK, supra note 63, at 106-07. For a critique of living wills as advancing a patient's competent wishes over later, imcompetent interests, see John Robertson, Second Thoughts on Living Wills, Hastings CENTER REP., Nov.-Dec. 1991, at 6.

79. See Dworkin, supra note 68 , at 7 .

80. Id. at 9.

81. See infra text accompanying note 86 .

82. See Buchanan \& BRock, supra note 63, at $60-65$ (arguing that "competence is a relational property determined by a variable standard," id. at 60 ). 
carry weight, even if less than the full weight which a fully competent expression would command.

Why should we defer to a decision to continue living inade by someone with the barest minimum of capacity for understanding and judgment? At bottom, I think the reason has to do with a general presumption favoring respect for a wish to live. At least two factors seem to be involved. First, there is the universality of the struggle to survive that we perceive in all hiving things, which makes it odd to justify disqualifying an expressed wish to live simply because of the person's cognitive limitations. Second, there is the seriousness and finality of what is at stake-tlie ending of a person's life. Buchanan and Brock have developed the case for taking into account the seriousness of the harmful consequences for the person in deciding whether he is competent. ${ }^{83} \mathrm{I}$ follow them here. Their approach is usually employed to justify overriding a person's choice to take a course that would greatly injure him or his interests (for example, a decision to refuse medical treatınent necessary to sustain life). But I see no reason why it should not also justify complying with his choice to take a course that would avoid those serious and perinanent consequences. Indeed, I am inclined to think that no person slould be regarded as so incoinpetent that his expressed wish to live slould be given no weight. I do not take issue with Professor Femberg that greater harm may possibly be done to a person by sustaining his life than by allowing it to expire. ${ }^{84}$ But I do not believe that this is the case where the patient, even thougl generally incompetent, is asking to be kept alive.

Dworkin, to the contrary, believes that "autonomy, on the integrity view of that right, inust be a general judgnient about [the person's] overall capacity to seek integrity and authenticity, not a specific, task-sensitive judgnient." 85 In his view, an autonomous person must have "the capacity to see and evaluate particular decisions in the structured context of an overall life organized around a coherent conception of character and conviction." ${ }^{86}$ This seems to me too restrictive a himitation on the right of autonoiny, for it would jeopardize the right to autonomy of many ordimary people who, by virtue of qualities of temperainent or character, appear to lack an ability to make choices on the basis of consistent life-organizing conceptions. I think, rather, that a major point of autonomy is to enhance the freedom to decide for oneself, whether one decides with authenticity and a sense of coherence or just on the basis of

83. Id. at 51. But see Mark R. Wicclair, Patient Decision-Making Capacity and Risk, 5 BIOETHICs 91, 104 (1991) (arguing that, although harmful consequences go to the necessity of deciding whether the patient is competent, they should not affect the standard used to determine competence).

84. See FeIngerg, supra note 24.

85. Dworkin, supra note 68 , at 10.

86. Id. 
immediate preferences and transient urges. An unwise, uninformed, and eccentric choice is still a choice. It may be that ideally, autonomy functions to permit people, to the extent they can, to make choices that create a coherent whole of their hives. But to deny a person his choices because he cannot choose in terms of a "structured context of an overall life organized around a coherent conception of character and conviction"87 would deny choice to an unacceptably large segment of the population.

But while precedent autonoiny (as Dworkin calls it) in our Composer's case falls short of the full moral force of conteinporary autonoiny, I have not argued that it has no force. What is there about the circumstances of Composer Now which warrants overriding the force it has? For me, and I expect for many, it is compassion for the human being before us, hiving her limited life in apparent contentment and evidencing no wish to end it. Letting her die when a cure is readily at hand requires a certain distancing of ourselves froin our human impulses, the suppression of a fundamental human empathy for another.

The choice to allow Composer Now to die is supported because earlier, when in full possession of her faculties, she stated that such a life for her would not be worth hiving. I do not inean to suggest that this is of shight inoment. As I said, it has inoral significance. But it does not have determinative significance. Without going so far as to regard Coinposer Now as a different person froin Composer Then, $I$ believe it is plam that there has oceurred a great transformation in her capacities and perspectives. If we deny her the treatment that would save her, the harm we do is immediate and palpable-we end a life of sharply limited but still contented experiences, in stark violation of our humane sensibihties. If we grant her the treatment we also do harm, but the harm we do is remote and intangible-we violate an exercise of precedent autonony which is so far separated and distant from her present circumstances that its entitlement to govern is severely coinpromised.

In the last analysis judgment turns on how much weight to give to the compassionate appeal of the person before us, as compared to the value of autonorny as a right to govern one's life according to a coherent normative structure. There is no algorithm for choosing. Still, those who choose, as I do, to give human coinpassion the greater weight have to confront whether the choice is a reflective, rational judgment or a reflexive, visceral response that should be the servant, not the inaster, of our judgment. This raises the great question of the foundation of our inoral judgments, which is quite beyond ine. I offer just these passing observations.

First, if the ultimiate value of autonoiny is its intrinsic value, then one may without einbarrassinent make the equivalent claim for compas-

87. Id. 
sion. Second, msofar as the ultimate value of autonomy hes elsewherefor example, in its being an essential ingredient of the good life, as Joseph Raz has argued ${ }^{88}$-it is relevant to observe that the sentiment of compassion for a fellow human being also serves a larger value, namely that it is an essential element in the very phenomenon of moral motivation and therefore of civilized society. Reflection, analysis, and theory contribute importantly to our understanding of the phenoinenon of inoral experiences, but it is the direct human experience itself that is the ultimate source of any vital morality. ${ }^{89}$

Third, compassion is not another word for personal squeamishness of the person making the decision. If it were, it would have the status of just one inore coinpeting interest of another person, coinparable to the interest of a relative in being reheved of the financial and psychological burdens attendant to the patient's continued life. But it is not just another's competimg interest; it rises to the level of a moral concern. This is because inorality has a dimension that has to do with the person doing the action as well as with the person being acted upon. The patient's right of autonomy is a moral concern of the latter kind; the actor's motivation stemming from the impulse of human coinpassion is a moral concern of the former kind. The well-known phenomenon of agent-centered restrictions on actions ${ }^{90}$ - moral restramts that inake it wrong for an agent to do an action that would produce the best available outcome overall (including the fewest actions of that same kind by others)-would not raise the profound problems for moral theory that it does were it not that morality has these separate dimensions.

One final comment on the Composer hypothetical is in order. I have been addressing it on the assumption that Composer expressed a desire to be kept alive-an assumption that makes it harder to justify letting her die. I have done so to allow me to consider Dworkin's argument, which accepts the challenge of this harder case. It is apparent, however, that the argument from compassion I have made applies as well

88. JOSEPH RAZ, THE MORALITY OF FREEDOM 415 (1986).

89. Cf. Mary Warnock, The Artificial Family, in MORAL DILEMMAS IN MODERN MEdicine 138, 154 (Michael Lockwood ed., 1985):

I disagree entirely with those philosophers who would claim ... that feelings alone cannot amount to a moral view, and that morality has to be a matter of reason. ... Indeed the whole notion of reason, on the one hand, and feeling or sentiment, on the other, essentially opposed to each other, seems to me to be a mistake-a hangover from an eighteenthcentury way of looking at things. I don't see why a moral view cannot both be grounded in feelings and at the same time (in some suitably broad sense) be rational, or at any rate not irrational.

See also the discussion of the distinction between the cognitive sense or concept of justice ("Rechtsbewusstein") and its emotional component ("Rechtsgefühl") in Wolfgang Fikentscher, The Sense of Justice and the Concept of Cultural Justice: Views from Law and Anthropology, 34 AM. BeHAVIORAL SCIENTIST 314, 316 (1991).

90. See Thomas Nagel, The View from Nowhere 164-88 (1986); Samuel Scheffler, THE REJECTION OF CONSEQUENTIALISM 80-114 (1982). 
to a modified Composer hypothetical in which it is not possible for her to express a wish one way or the other. That she expresses a wish to live adds the appeal of autonomy to the appeal of compassion (as well as contributing to it), but I beheve the appeal of compassion is enough without it.

\section{B. Where the Patient Never Chose: Substituted Judgment}

I turn now to what are called "substituted judgment" cases, those in which a person now incompetent never exercised a choice when competent. As I have indicated, the courts try to deal with incompetents the same way they deal with competents, namely by seeking to determine the person's choice. But how do you find a choice when none has been made? Courts have responded by looking for what the patient would have chosen: What would this patient choose if he were competent to appraise his situation, including his medical condition and prognosis, as well as his present and future incompetency? ${ }^{91}$

This standard is puzzling because it implies that we are to ask what the permanently incompetent person would now choose if he were competent to choose and aware of his imcompetency, as if this would tell us what an incompetent would choose. But it cannot be known what an incompetent person would choose precisely because he caimot choose. We can try to imagime that he is temporarily competent and inaking a choice that takes into account his anticipated incompetency. But this is a very different thing. Like an advance directive, it would be the choice of a competent patient anticipating, but not actually experiencing, his life as an incompetent; the choice, in short, of the person as he was, not as he now is, because he is now incapable of choosing. ${ }^{92}$ This is, I think, all that courts can mean by the usual statement of the substituted-judgment standard.

This distinction may seem like a cavil, but it serves to avoid the kind of error a Massachusetts court made in considering whether to forgo medical treatment for an elderly incompetent person who had been incompetent his entire life. The court stated:

In short, the decision in cases such as this should be that which would be made by the incompetent person, if that person were competent, but taking into account the present and future incompetency of the individual as one of the factors which would necessarily enter into the decision-making process of the competent person. ${ }^{93}$

91. For discussion and criticism of the substituted-judgment standard, see BuCHANAN \& BrocK, supra note 63, at 112-17; PrEsidenT's CoMm'N, supra note 1, at 132; Developments, supra note 27 , at $1646-51$.

92. Cf. Louise Harmon, Falling off the Vine: Legal Fictions and the Doctrine of Substituted Judgment, 100 YALE L.J. 1, 58 (1990) (discussing substituted judgment as developed in 19th century England to govern expenditures of lunatics' income).

93. Superintendent of Belchertown State Sch. v. Saikewicz, 370 N.E.2d 417, 431 (Mass. 1977). 
The trouble with this approach is that it requires finding something which isn't there to be found, since the patient was never competent to make a choice. ${ }^{94}$

Another question raised by the substituted-judgment standard, even interpreted as I have argued it should be imterpreted, is this: To what extent is it required by the patient's right of self-determination? In the Composer hypothetical, I considered that question in connection with advance choices generally, and concluded that while the right of autonony was indeed involved (because the patient exercised choice at some time in the past), the advance choice might in soine circumstances lack the full moral force of a contemporaneous choice. The substituted-judgment standard entails the same difficulty since the evidence of what the patient would have chosen is in the patient's past. But this standard has an additional difficulty; namely, that it is invoked where there has been no choice by the patient at all, either in the past or now. Courts applying this standard search for evidence of the patient's past life in order to determine how he would have chosen. But whatever the justification for this standard may be (I shall argue it is best understood as part of a bestinterests assessment), it cannot be based on the autonomy principle. In these cases we cannot say that the patient has the right that his choice be respected, because he has made none.

The reason for this hes in the distimction between evidence of what a patient would choose and an actual choice. ${ }^{95}$ The right of autonomy is the right to have your own choices respected, not to have someone else make the choice he behieves you would (or should) have inade. The right protects your act of choosing. When someone else makes the choice, even if he chooses as he thinks you would, he is making the choice, not you. Since you made no actual choice, if he chose to disregard evidence of what you would have chosen, he would not be violating your autonomous right to choose.

Why should an actual choice be that crucial? Aren't there many cases in which the past life of the patient allows us to conclude with reasonable assurance that, if competent, he would have chosen a certain way? Surely this is so. The reason this is nonetheless not equivalent to an actual choice turns on a view of what an exercise of will entails. The

The Massachusetts court continues to adhere to this analysis. See Guardianship of Jane Doe, 583 N.E.2d 1263 (Mass. 1992).

94. See President's Comm'N, supra note 1, at 133; TRIBE, supra note 57, at 1369 (noting that attempting to effectuate "patient's subjective wishes reaches almost Alice in Wonderland proportions"); Daniel Wikler, Patient Interests: Clinical Implications of Philosophical Distinctions, 36 J. AM. GERIATRIC Soc'Y 951, 956 (1988).

95. In support of this distinction, see BUCHANAN \& BROCK, supra note 63, at 116 (evidence of individual's preference does not carry same moral weight as individual's deliberate choice); Dworkin, supra note 68, at 13-14 (appeal to precedent autonomy requires an actual choice by patient in past); Rhoden, supra note 27, at 389 (right to autonomy is not violated absent actual choice). 
view I am taking is that the will of a person stands apart from his character and dispositions; it is not one among other characteristics that, summed up, go to make the person what he is. Everything the person is and was may point to him doing $\mathrm{X}$ in some particular circumstance. But he is free to do not-X, and may do so, no matter how out of character it seems. The phenomenon of weakness of the will illustrates this point. Even when a person acknowledges that, froin the standpoint of every relevant criterion he accepts he should do $X$, he may still choose not to do $X$. Just as a baseball game, in a notable aphorism, is "not over till it's over," so a choice is not made till it's made.96

Of course, it will sometimes be difficult to distinguish between an actual decision made in the past-and thus subject to autonomy considerations-and evidence of conduct pointing to what the patient would have decided. A written advance directive would be a clear case of the former. But the patient may have decided im less formal ways, such as by orally revealing his decision to others. By contrast, examples of the latter would be the patient's general reflections on the subject of dying, positions he had taken in discussion with friends, religious commitments that would suggest one position or another, and so on. These may give us clues to what his decision would be had he made one, but they are not decisions. There may be difficulties in applying this distinction, but that does not undermine the distinction in primciple.

It does not follow from this distinction that evidence of the patient's preferences has no relevance. It plays a role in assessing his best interests, as I will argue. I only want to claim that cases of presumed preference are not morally equivalent to cases of actual choice, express or imphed. This point is inportant because it allows us to see that, while in cases of contemporaneous choices (and, though to a lesser degree, in cases of advance choices as well) respect for autonomy requires doing as the patient directed, this is not so in substituted-judgment cases. Here, the deciding agent is obliged to make its own choice, the values and preferences of the patient in his competent state serving as guide to a bestinterests judgment. Recall Composer Now and Composer Then. In order to make the case for treatment I had to justify compromising Composer Then's right of autonomy. Absent her directive not to treat, however, I would not have had to face that issue, because her autonomy would not have been involved. .

The point has further import. So long as the ultimate issue is narrowly thought of as one of substituted judgment-that is, what the patient would choose if he could-there is some logic to courts insisting on a demonstration of that fact with a high degree of evidentiary certi-

96. There is a political dimension to this view of autonomy: it defeats an attempted justification of unconsented-to authoritative actions based on the view that those affected would consent and therefore may be taken to have done so. 
tude. This was the narrow issue in the Cruzan case, in which the Supreine Court upheld the Missouri law requiring "clear and convincing proof" that the patient would choose to terminate treatınent. ${ }^{97}$ Viewing the task more broadly, however, as involving a construction from all the circumstances of what treatment decision coinports best with the hife and character of the patient and therefore furthers his best interests, changes the focus of inquiry. It puts the issue of proof in a more appropriate and reahistic framework: not "Unless it is demonstrated with a high level of certainty what the patient would have chosen, treatinent inust continue," but rather, "Froin the evidence that is available, including the character and attitudes of the patient, what decision-to continue or terminate treatınent-will serve his best interests?"98

\section{III}

\section{BEST INTERESTS}

The Enghish courts of equity developed the best-interests standard to govern expenditures froin the estates of incoinpetent persons. ${ }^{99}$ But the standard has proved to be highly controversial in cases of incompetents who require medical treatment to stay alive. ${ }^{100}$ There is concern over the appropriateness of the standard to determine whether a person should live or die and over how the concept should be imterpreted and applied.

A fundamental objection arises from what is imphicit in the standard, at least when understood apart froin the setting of the patient's inferred preferences: that in certain circumstances the quality of a person's life may be so low that it is not worth living. This stands in stark opposition to the tradition that human life is always valuable. It is one thing for courts to defer to the patient's choice to die. This has proved difficult enough for some courts, as we saw, but at least the decision requires no judgment by the court or some other agent that the patient's hfe is no longer worth hiving-only that this is the choice of the patient whose life it is. It is quite different when the best-interests standard is applied mdependently of the patient's inferred preferences, because this requires the deciding autlority itself-the court or some other agent-to make the substantive judgment of whether what is left of the patient's life is worth the candle.

One concern animating this objection is that assessing the quality of the patient's life requires a judgment of its social worth. As one court put it, it is improper "to authorize decision-making based on assessments of the personal worth or social utility of another's life, or the value of

97. Cruzan v. Director, Mo. Dep't of Health, 110 S. Ct. 2841, 2846-55 (1990).

98. Nancy Rhoden has made a similar point. See Rhoden, supra note 27, at 390.

99. The history of the doctrine is told in Harmon, supra note 92, at 16-55.

100. See Developments, supra note 27, at 1651-53. 
that life to others" because to do so creates "an intolerable risk for socially isolated and defenseless people suffering from pliysical or mental handicaps."101 Yet this concern seems misplaced, for there is nothing in the nature or history of the standard that requires judgments of the patient's worth to society generally or to particular others. Applied to the decision whether to treat, the accepted understanding of the bestinterests standard is that it seeks to assess what would be best for the patient, not for his family, others, or the coinmunity as a whole. ${ }^{102}$

Even so, courts have found that judging whether a patient's future life is not worth living is a troubling decision for anyone to make. First, what makes a life not worth living anyway? Loss of the patient's cognitive powers, his ability to function independently, his ability to interact with others, his dependence on constant medical intervention? How much ability to sense and take comfort from experiences is required before we can say his life is not worth hiving? At bottom, the difficulty is that we have no way to make confident judgments about how far cognitive and physical deterioration must go before life ceases to be worth living, because the value judgments imphicit in such a conclusion are in sharp contention in our society. ${ }^{103}$ Second, there is the challenge of "don[ning] the mental mantle of the incompetent,"104 understanding and judging his experiences as he lives and feels them, rather than from the biased perspective of a normally healthy person with unimpaired faculties. Finally, courts are often troubled by the specter of the slippery slope-the fear that once the precedent is established that a person may be left to die because someone judges his hife not satisfying enough to be worth living, there will be nothing, or at least less, to stand in the way of that judgment being made of socially, mentally, and physically handicapped people on the margins of society. ${ }^{105}$

Courts have tried in various ways to allay these concerns. The efforts of the New Jersey Supreme Court in Conroy, ${ }^{106}$ a case that attracted wide attention, are particularly instructive. In an effort to defeat the slippery slope, the court established the requirement of severe

101. In re Conroy, 486 A.2d 1209, 1232-33 (N.J. 1985).

102. See Suzanne Levant, Case Comment, Natural Death: An Alternative in New Jersey, 73 GEO. L.J. 1331, 1337 (1985) (arguing that decisions should be made solely from patient's perspective).

103. See TRIBE, supra note 57, at 1369.

104. Superintendent of Belchertown State Sch. v. Saikewicz, 370 N.E.2d 417, 431 (Mass. 1977) (quoting In re Carson, 241 N.Y.S.2d 288, 289 (Sup. Ct. 1962)).

105. See Conroy, 486 A.2d at 1233 ("More wide-ranging powers to make decisions about other people's lives... . would create an intolerable risk for socially isolated and defenseless people suffering from physical or mental handieaps."); Cruzan v. Harmon, 760 S.W.2d 408, 420 (Mo. 1988) ("Were quality of life at issue, persons with all manner of handicaps might find the state seeking to terminate their lives."), aff'd sub nom. Cruzan v. Director, Mo. Dep't of Health, 497 U.S. 261 (1990); see also Saikewicz, 370 N.E.2d at 432 (court bridled at suggestion that quality of life available to retarded person should be considered).

106. Conroy, 486 A.2d at 1232. 
irremediable pain and suffering as a condition for any assessment of the quality of the person's life. ${ }^{107}$ But inedicine's considerable success in finding ways to suppress pain has largely eliminated pain as a reason for letting a person die (in contrast to the impaired quality of life which pain suppression can entail). ${ }^{108}$ Pain is one, but hardly the only, circumstance that might make a patient's life so burdensome that his best interests lie in extending it no further. Hence, requiring the presence of pain excludes other situations in which quality-of-life considerations may call for terminatimg treatment. ${ }^{109}$

Two other, nore felicitous moves by the court to avoid the worst dangers of quality-of-life judgments were first, to preclude judgments based on the social utility of the patient's life or on its value to others, ${ }^{110}$ and second, of more direct relevance to my arguinent, to require that enough be known about the patient to make a reasonable inference as to his likely preferences before a judgment of his best interests is permissible. ${ }^{111}$ This constitutes a helpful reorientation of the substituted-judgment standard. It properly identifies the reason for consulting the patient's inferred preferences: not because it serves his autonony, but because it furthers his best interests, on the view that inaking a treatment decision truest to the kind of person he was informs a best-interests judgment. Of course, if there were evidence that he inade an actual choice when competent to reject treatment in the circumstances presented, his right of autonoiny would require doing as he chose unless soine powerful consideration required doing otherwise (as in the case of Composer Now). However, we are here considering cases where evidence of such a choice is insufficient, but where there is evidence of the kind of person he was. How should this evidence be appraised in making a best-interest judgment?

Certainly evidence of the values that guided the patient's coinpetent hfe (what Ronald Dworkin calls his "evaluative interests" 112)-his character, how he led his life, his attitude toward medical treatment, what it was about life that he thought made it worthwhile, how much it mattered

107. Id. The court held that treatment may be forgone when the pain reaches the point "that the net burdens of [the patient's] prolonged hfe markedly outweighs any physical pleasure, emotional enjoyment, or intellectual satisfaction that the patient may still be able to derive from life." Id.

108. President's CoMm'N, supra note 1 , at 19, 50-51. However, there are a variety of social and institutional restraints-for example, inadequate medical education in pain management and fears of addiction-that hinder the use of available knowledge. See Kathleen M. Foley, The Relationship of Pain and Symptom Management to Patient Requests for Assisted Suicide, J. PA1N \& SYMPTOM MGMT. 289 (1991).

109. It is instructive that even the dissenting justice in Conroy, while rejecting the requirement of pain, thought it necessary to require that the patient be facing imminent death, be incurable, in a comatose state, and suffering the loss of at least one major bodily organ or system. Id. at 1244, 1249 (Handler, J., dissenting).

110. Conroy, 486 A.2d at 1232-33.

111. Id. at 1231-32.

112. Dworkin, supra note 70 , at 32 . 
to him that he was burdening others, how sensitive he was to considerations of privacy and personal dignity-bears directly on a best-interests judgment. But there is another kind of consideration that needs consulting as well; namely, the patient's present experiences or lack of them (what Dworkin calls his "experiential interests"113). These include the patient's medical prognosis, the extent of his suffering, the degree of his mental and physical impairment, and the kind of experiences he would be capable of if he survived. The question then becomes whether, on the basis of both kinds of evidence, we can conclude that a decision to forgo treatment would be consonant with the kind of life he led and the kind of person he was, as well as with the kind of person he is now. If so, we can conclude that it is in his best interests to deny treatment.

Some regard evidence of the first kind-evaluative interests-as irrelevant, on the ground that one can have no interest in what is not and can never be experienced; under this view, only experiential interests count in cases of serious and permanent mental disability. ${ }^{114}$ This argument has an attractively down-to-earth appeal, but as Joel Feinberg and others have shown, denyimg that a person's interests may be harmed when he does not and can never experience the harm takes too narrow a view of an interest. ${ }^{115}$ Consider posthumous harms. There is a natural sense in which the interests of a person who is no longer alive may be harmed. Such harm occurs when that which he deeply cherished and to which he devoted his life suffers destruction, when his valued reputation as a person of honor and distmction is destroyed by malicious lies, or when significant promises he exacted to be performed after his death are foresworn. For like reasons, the evaluative interests of a living person

\footnotetext{
113. Id.

114. See, e.g., Dresser, supra note 27, at 389:

Legal decision-makers have accepted the dubious notion that what was vitally important to incompetent patients when they were competent remains vitally important to them in their imcompetent states. But incompetent patients differ from competent patients in material ways that invalidate this notion. Incompetent patients are incapable of appreciating the values and preferences they once held dear. As a consequence, standards attempting to honor those values and preferences fail to advance the incompetent patient's present welfare.
}

See also John A. Robertson, Cruzan and the Constitutional Status of Nontreatment Decisions for Incompetent Patients, 25 GA. L. REV. 1139, 1158-62 (1991).

115. FEINBERG, supra note 24, at 83-95 (1984) (arguing that people have interests that survive their death); see also Conroy, 486 A.2d at 1229:

The right of an adult who. . . was once competent, to determine the course of her medical treatment remains intact even when she is no longer able to assert that right or to appreciate its effectuation. As one commentator has noted:

Even if the patient becomes too insensate to appreciate the honoring of his or her choice, self-determination is important. After all, law respects testamentary dispositions even if the testator never views his gift being bestowed.

...

Any other view would permit obliteration of an incompetent's panoply of rights merely because the patient could no longer sense the violation of those rights.

(citations omitted). 
(his sensibilities, his concerns for his own dignity and for not burdening others, his prized self-determination) may be harmed by how we deal with him after he has permanently lost capacity to be aware that these harms are being done to him. The Composer hypothetical would not have been so difficult were it not that Composer's interest in having her right of autonomy respected continued even though she could not (and could never) experience it. It is important to stress that this approach to ascertaining best interests offers some protection against the feared precedent of permitting someone else's judgment of the quality of a patient's hife to determine whether the patient should be permitted to die. It does so because it makes the patient's own value structure controlling of whether it is consistent with the patient's best interests to forego treatment.

Ronald Dworkin, to the contrary, has proposed that except in cases where the patient has made a coinpetent choice for treatment sufficient to invoke his right of autonomy (Dworkin agrees that evidence of preferences short of such choice are insufficient to invoke this right, $)^{116}$ the standard of evaluation of the worth of the patient's continued life (his evaluative interests) should be objective rather than subjective. In other words, the standard should not be necessarily what the patient himself would regard as in his best interests, but what is in his best imterests, period. Referring to patients with permanent and severe dementia, he concludes that:

a fiduciary should take over a person's responsibihity to make his life as good a hife as it can be when that person is no longer capable of this himself .... [ $] \mathrm{t}$ t follows that the right to beneficence includes the right not to be given life-prolonging treatment when seriously and permanently demented. ${ }^{117}$

This follows for Dworkin because a permanently and seriously demented person's life can contaim nothing that would make his life better. Lacking a "sense of personality and agency," his experiences could not be rewarding. ${ }^{118}$ And lacking "continuity of project and fulfillment," they could not be regarded as achieveinents. ${ }^{119}$ On the other hand, a demented life can contain experiences that make the hfe of which it is a part worse-experiences of anxiety and pain, for example.

116. Dworkin, supra note 68, at 13-14 (stating that right depends on evidence of "an actual past decision contemplating the circumstances the patient is now in"). Despite this formulation, Dworkin apparently beheves it would be sufficient to invoke the right of autonomy if "we have good reason to think he would have made that request [to be kept alive] if he had thought it necessary." Dworkin, supra note 70, at 50 . Of course there does come a point where the inference of a choice from an expressed preference is so strong that it counts as a choice. There is room for disagreement on precisely when this point is reached. I understand Dworkin to mean that his test should be applied in all cases where the inferred prefcrence is not that strong.

117. Dworkin, supra note 70 , at $48-49$.

118. Id. at 47.

119. Id. 
What I have given of Dworkin's argument for an objective bestinterests judgment is the barest outline, which fails to convey its subtlety and complexity, but it is enough to allow me to say why I find it troubling. First, a basic premise of Dworkin's argument is that it is in the best interests of a patient that a decision makes of the patient's life as a whole as good a thing as it can be, one marked by a sensitivity to values of privacy and dignity, by respect for and deference to the interests of others, and so on. This evokes his theory of adjudication as interpretation, requiring the judge to make of the law as good a thing as it can be. ${ }^{120}$ But there is an important difference, for I doubt that a person's life is made better by decisions that are not rooted in him as a person. If a person during the course of his competent hife has been indifferent to matters of respect for his person and for the interests of others, it does not seem to ine that it serves to make his whole life a better one that in the end someone has made decisions for him which manifest these virtues. They are, after all, imposed on him and hardly do him credit.

Moral luck plays some role in the living of a good life, ${ }^{121}$ and on that basis an argument can be made that the patient's good fortune in being permitted to die after suffering serious and permanent dementia makes his whole life, on balance, a better one than it would be if he were kept alive. But this seems unconvincing. Luck may be a factor in permitting a person to lead a good life, but to say that lis life is inade a better one because a good thing luckily happened to him after he had finished leading his life yields too much to the authority of fortune. It is a bit like flowers on a grave: they make lots of things better, but scarcely the life of the person beneatli them. Consider the example of being a burden to others, often given as one among a set of reasons for declining treatment: it is a virtue for a person to permit himself to die to save burdening otliers, and he makes his whole hife a better one for doing so. But it hardly inakes his life a better one that a third party decides to sacrifice it for the benefit of others.

My second reason for demurring to Dworkin's conclusion is practical: it invites the danger that many courts and commentators have seen in best-interests standards-tlie danger that those making the decision cannot be relied on to keep separate what is objectively best and what is best for them. It is often in the interest of those around the demented patient that he be permitted to die-he is a psychological burden to them, the ininistrations required for his bodily functions often offend their sensibilities, lie requires the use of valuable resources, and the positive qualities of his limited life seem sliglit coinpared to the negative influence on the lives of others. We may insist that it is in his best interest that lie be allowed to die, but when that decision is one that serves the

120. See Ronald Dworkin, Law's Empire 225 (1986).

121. See Thomas Nagel, Mortal Questions 24-38 (1979). 
interests of others (who often are the ones making the decision) there is the ever-present danger that it is their interests, not his, that are motivating the decision.

Another problem with Dworkin's position is that it is, most uncharacteristically for him, paternalistic, at least in the sense that it makes the final act in a person's life turn on the normative standards of others rather than on those of the person himself. Dworkin accepts that a demented person's earher competent choice for treatment must prevail even if it is against what Dworkin would regard as his best evaluative interests, considered from an objective perspective. But there are plainly going to be cases where the person's life has left evidence consistent with a preference for continued treatment, although he made no actual or implied choice to which his right of autonony would require deferring. It seems to me that we should want to say that such a person has an mterest, that it is im his best interests, that the decision accord with his own values and preferences as best we can discern them. I agree that it would not violate his right to autonomy to disregard his inferred preferences (since he made no choice). Nonetheless, it would be inconsistent with his interest $\mathrm{m}$ having the end of his life governed by the kind of choices he made to govern his competent earhier life, and therefore, in this sense, paternatistic.

Nonetheless, there are situations where Dworkin's analysis has a strong appeal. These are the cases where we can make no reliable judgment based on the person's past values and commitments, either because the evidence is totally indeterminate or because he never was competent. Here it is not possible to tailor the choice to the character of the person. In this situation a decision that can be supported as better on impersonal, objective grounds is obviously preferable to a decision that cannot be so supported.

My final concern, which I suggested earlier in a related context, is that Dworkin's position unduly discounts the experiential interests of a demented person-the satisfactions that can come from sensory experiences and coinforting feelmgs that do not require higher-order mentation. To paraphrase Bentham, the question is not whether demented people can reason, nor whether they can talk, but whether they can feel. 122

\section{IV}

\section{CONCLUSION}

I conclude with a restatement of some of the positions I have tried to defend.

122. In deploring the tormenting of animals, Bentham wrote: "[T]he question is not, Can they reason? nor, Can they talk? but, Can they suffer." JEREMY BENTHAM, AN INTRODUCTION TO THE Principles of Morals and Legislation 283 n.b (J.H. Burns \& H.L.A. Hart eds., 1970). 
A constitutional right of autonomy has provided the foundation for judicial treatment of decisions to let patients die. In principle this right extends to suicide and assisted suicide, although the extension could be resisted on plausible prudential grounds. The courts, however, have sought to distinguish suicide froln cases of letting patients die on such grounds as the doing/allowing and purpose/knowledge distinctions, which have failed to carry the burden put on them.

The principle of autonomy controls the decision whether to let a patient die when there is a competent contemporary choice. In all other cases, it becomes just one of several factors to consider.

For reasons I suggested im connection with the Composer hypothetical, an advance competent choice has force, but not the conclusive moral force of a conteinporary choice and not so much force as to preclude consideration of the possibly conflicting experiential imterests of the patient.

Where the patient never made a choice during his coinpetency, the right of autonomy is not implicated at all, contrary to what courts assume under the substituted-judgment standard when they seek to discover what the patient would have chosen. What we think he would have chosen is not what he chose. A judgment based on a search of the patient's competent life for his preferences, values, and commitinents is appropriate not because it is required by his autonomy right but because it is in his best interests.

The patient's interests imclude his experiential interests-the quality of his future life if kept alive-as well as his evaluative ones, and if it is his best interests that are to be furthered, any judgment upon them must be made with reference to the values and commitinents by which the patient chose to lead his life. For reasons I have tried to suggest, this subjective approach to determining his best interests is preferable to an objective one, which would seek to nnake his life as a whole a better one in terms of some objective criteria of the good life, but not those of the patient whose life we are deciding. 